UDK: 821.111(94).09

DOI: 10.4312/an.49.1-2.19-27

\title{
Celebrating Downward Mobility in Selected Australian Texts
}

\section{Margarete Rubik}

\begin{abstract}
Several critics have pointed out that the new lower class national hero from late $19^{\text {th }}$ century onwards was invariably male, and that women were largely excluded from this national stereotype. Yet several recent Australian authors have portrayed female characters who correspond to this insubordinate, defiantly lower class ideal, and thereby insert women into the national myth.
\end{abstract}

Keywords: Australian fiction, Kate Grenville, D. H. Lawrence, Murray Bail, Barabara Jefferis 
It is a well-known cliché that from the end of the $19^{\text {th }}$ century onwards, Australian fiction tends to be peopled with heroes who are working class and anti-authoritarian, who are loyal to their mates and distrust figures of authority. These attitudes have been traced back to the convicts' dislike of soldiers at the beginning of settlement, to the Eureka stockade and the breakdown of the class system in Australia. Several critics have pointed out that this new lower class national hero was invariably male, and that women were largely excluded from this national stereotype. Yet several recent Australian authors have portrayed female characters who correspond to this insubordinate, defiantly lower class ideal, and thereby insert women into the national myth.

Students with little experience in Australian fiction but alert to conflicts of race and gender frequently dealt with in American or British literature, often fail to appreciate the egalitarian social spirit and proud lower class stance encoded into legends like that of Ned Kelly and other texts. But perhaps this partial blindness should not really be surprising, given the radical departure of Australian sagas from the myths current in Europe. Children in Europe would have been brought up on the Cindarella myth and the dream of rags to riches. The typical European fairy tale sees a poor girl raised to the heights of social advancement by an appreciative Prince Charming, or an impoverished but worthy lad overcoming all obstacles and rising to the top on account of his talent and industry. It is always a myth of upward social mobility, of climbing the social ladder and leaving behind what is conceived of as a life of poverty and misery. The scandal surrounding sensation novels or D.H. Lawrence's Lady Chatterley's Lover was as much about class as it was about the explicit presentation of sex. The offence the latter novel gave is also intricately linked to the outrage of an upper class lady giving up her class status to find sexual fulfilment in the arms of a virile game keeper.

There are interesting parallels between Lawrence's scandal novel and Murray Bail's short story The Drover's Wife, a text responding to both Henry Lawson's famous original and Russell Drysdale's painting of this typical Australian motif. In this story, the middle class narrator, a dentist formerly married to a woman who is now the drover's mate, is scandalized by the fact that she blithely gave up her middle class life and ran away to consort with a lower class man. Throughout her marriage with the dentist, the woman refused to conform to norms of lady-like behaviour and embarrassed her husband by her physical robustness and delight in manual labour which, he feared, might make the neighbours talk.

... the sight of sweat patches under her arms, for example, put me in a bad mood. It irritated me the way she chopped wood. I think she enjoyed chopping wood. There was the time I caught her lugging into the house the ice for the ice chest ... The ice man did not seem to notice; he was following, working out his 
charge.... And then of course she killed that snake down at the beach shack we took one Christmas ..." (Bail, 257f.)

The last incident, of course, gestures back to the original narrative of "The Drover's Wife". But while Lawson's short story of 1892 is firmly rooted in a lower-class milieu only, Bail dramatizes a class conflict and makes the woman take an active step of affiliation with a man of the lower social orders, defiantly rejecting middle-class respectability. Hence the narrator smarts all the more under the opprobrium of having lost out to a man whom he despises as a social inferior. His wife went, so to say, over to the class-enemy, thereby reasserting herself as a typically Australian heroine. It is also characteristic that she was neither bothered by the bush flies nor by the heat during the camping holiday he recalls. The dentist, on the other hand, hated the bush, the typical setting of so much of Australian early fiction: “...I have no desire to return, none.... I felt lost. And during the day the bush, which is small and prickly, offered no help (I was going to say 'sympathy'). It was stinking hot" (Bail, 258). Through his behaviour and preferences he exposes himself as an urban, middle-class Australian anti-hero, whose snobbishness and class consciousness are shown to be the antithesis of the positive Australian stereotype.

Barbara Jefferis has spun on Bail's rewriting of the story of the drover's wife in her own narrative of the same title. It features the woman herself as a narrator taking issue with the way male writers have presented her in their stories and recounting how, at the age of sixteen, she ran away with the dentist to escape the squalor and abject poverty of her home. The man evidently expected her to be properly grateful for raising her to middle-class status and

...couldn't understand you could give up a board floor and a bit of carpet and some wax fruit under a glass bell for a shack with no floor at all in the kitchen and water that had to be carried half a mile when the tank ran dry. (Jefferis, 270)

Like Lady Chatterley, however, she prefers the drover's virility to the narrow-mindedness and fastidiousness of her middle-class husband: "There's more to a man than trimmed nails and a dark suit, and I'd rather have beer fumes breathed in my face than fancy pink mouth-wash" (Jefferis, 173). The dentist's squeamishness and misogyny are ridiculed in Jefferis' short story, which invites sympathy with the woman's cheerful downward social mobility and escape from her middle-class cage. She leaves her egotistic bourgeois husband and marries a drover, being satisfied with her new life in the bush despite its hardship and her supposed social descent.

We encounter a similar scenario in the popular movie Australia. To be sure, the aristocratic heroine's husband has been killed, so she does not commit adultery, 
but, like Lady Chatterley and Bail's and Jefferies' drover's wives, Lady Ashley is happy to cross class barriers downwards, instead of upwards, as is the wont in European myths. Embracing an egalitarian dissolution of class divisions, the European aristocrat, somewhat improbably, falls in love with - again -a drover, visualized as a rough but emphatically virile working class man. After the initial social clash between the future lovers, the conflict in the film, interestingly, is not between the upper and the lower class - they quickly find common ground, with the Lady turning into a cowgirl overnight - but between the small cattle owner and the bourgeois capitalist entrepreneur. As in Bail's story, the middle-class are the true antagonists.

In the following, I would like to focus on two of Kate Grenville's novels: Lilian's Story - as a paradigm of this Australian celebration of downward mobility in order to escape from the middle-class prison-house of convention - , and The Secret River, depicting an earlier historical phase, when characters still remain enmeshed in British class values, even though they were forcibly transported as convicts and stem from the very class which suffered most under the unjust social hierarchy in the mother country.

Traumatized by childhood experiences of abject poverty and starvation, social humiliation and a series of unfortunate circumstances dashing his hope of financial security, William Thornhill, a boatman on the river Thames, was sentenced to transportation for attempting to steal some timber. Determined to rise in the new world after his release, he buys land on the banks of the Hawkesbury River (the eponymous Secret River).

In Thornhill's world, a person might own some sticks of furniture, a few clothes, perhaps a lighter. That was wealth. But no one that Thornhill knew personally had bought so much as a yard of land. (Grenville, Secret River, 109)

Landed property, in eighteenth century England, would have been a qualification for gentrification. Indeed, in his negotiations with the Aborigines on whose land he has built his farm on the basis of the fiction of terra nullius, he adopts the very tone the rich assumed vis-a vis-the poor boatman in London:

Old boy, he started. He fancied the sound of that. He had never called anyone old boy the way toffs did. Bugger me, you are making no sense whatever! It was the way gentry had spoken to him wanting him to row faster... (Grenville, Secret River, 148-149)

He finally becomes a rich man - but at the terrible price of participating in a massacre of an Aboriginal tribe supposedly threatening the white farmers. Greed for land-ownership, thus, tempted him to burden his conscience with a deed he 
knows he can never atone for. Thornhill's dogged determination to own this piece of land in the Hawkesbury valley, his mimicry of an upper-class mien, just like his later whim of ordering stone lions from Britain to guard the entrance to his estate, indicates how much he is still part of the old world - although, unlike his faithful wife Sal, he has never dreamed of returning to England, knowing well that money can never wash off the stain of transportation in his old mother-country. However, the stone effigies he buys at great cost cannot compare to the glorious specimen guarding the entrance to St Paul's Cathedral which so impressed him in his youth. Neither can the portrait of himself he orders an artist to paint fool anyone as to his true class origin - a perpetual reminder to him that having made it in Australia is still a long way from being acceptable in British society, and a reminder to the reader that Thornhill has failed to extricate himself from British class ideology and continues to exhibit a traumatic need to define himself in terms of the very class which constantly made him feel his own social inferiority in the old world.

$\mathrm{He}$ is, in fact, the exact opposite of the late nineteenth century egalitarian ideal: he refuses to fraternize with his former London mates when he meets them again as convicts, but treats them as indentured servants he has hired to work for him - another betrayal of his former kindly principles. Thornhill is an Australian self-made man and founds a dynasty, rising from convict to rich landowner, but in his dream of upward social mobility he remains intricately bound up with his former British background.

In contrast to The Secret River, Lilian's Story celebrates downward mobility as liberation. The novels deals with a woman born into a middle-class Australian family in the early twentieth century who rejects her background and conventional gender roles and ends up as an eccentric street-person. She makes a living by offering recitations from Shakespeare, hijacks taxis with passengers to gain an audience, loves to cause a public disturbance and gains notoriety and fame.

Lilian's Story is based on a real-life figure, Bea Miles, whom as a girl Grenville frequently saw, as she says "from the safe distance of a bus" (Grenville, "Readers' Notes"). Bea had gone to one of Sydney's top schools and had later dropped out of University. She had been institutionalised as insane but had gained "the freedom of the city" (Barcan 31) and had become a figure around whom "myths and stories accumulate" (Ashcroft 55). Grenville was intrigued by this "loud, uninhibited ... bag-lady, with no fear of what people thought and no sense of what she 'should' be." (Grenville, "Readers' Notes"). However, she did not want to write a biography but took Bea's life story as a departure for investigating the question of how a woman of her time could have escaped the gender and class limitations imposed on her.

What does it mean to refuse the life-story that has been prepared for you, and choose another of your own making? ... Bea Miles should have grown up to be 
a conventional wife and mother but had forcefully re-written the script for her life." (Grenville, "Readers' Notes”)

Fat and ungainly, brash and unfeminine, Lilian from the beginning fails to conform to the rules of ladylike behaviour: "Lilian, do not bang your feet like that, ... A lady glides, Lilian." (Grenville, Lilian's Story, 6) her mother admonishes, but Lil stomps instead of gliding, tries to emulate the boys in daring and is consigned to the role of an outsider, rejected by her classmates, her parents and the society in which they move. When she tries to break out from her father's tyrannical regime, he rapes her, a shock from which she recovers by spending time in the bush - which again marks her as a genuinely Australian heroine. She scandalizes the inhabitants of a tiny village by walking to the pub stark naked and later escapes from home every evening to spend the night alone under the stars on the beach. But as Barcan points out, such "escapes from order often produce a backlash from those in power" (Barcan 39), who are threatened by such insubordination. Her father has her confined to a lunatic asylum, from where she is freed by a sympathetic aunt, who blackmails her father into giving Lil an allowance. Still later, she joins a homeless old admirer who lives in a storm drain in the park.

In their interpretations, most critics have concentrated on gender issues, but Lil's rebellion is as much against class rules, or rather, gender and class are firmly intertwined. Lil is born in the year of Federation, in 1901, and just as in the case of Rushdie's Saleem in Midnight's Children, her life in some ways reflects the development of the new nation. Unlike Rushdie, however, Grenville is not interested in political history, but Ashcroft has perceptively commented on the parallels between the successful decolonisation of Lil's mind from patriarchal oppression and the emancipation of Australia from colonial oppression. Significantly, Lil causes a disturbance when she refuses to rise for the British anthem in a movie theatre. And her father, against whom she rebels, is, significantly, called Albion. Yet a second parallel can be pointed out. Like the new nation, Lil also emancipates herself from English class values and becomes a typically Australian heroine: lower class, anti-authoritarian, and valuing mateship. She shouts at the judge in court and hitches up her skirts to show some taunting policemen her bottom. As long as she craves social acceptance, she is under the thrall of the "power of social convention, which Lilian ultimately defeats by becoming a homeless peripatic "character" (Ashcroft 56). Only when she opts to remain outside "the normative positions of gender and class" (Livett 119) can she gain autonomy over her life. It is important to remember that she puts herself quite outside the class system. Typically, she befriends those who are also socially marginalized: prostitutes, the insane, the homeless. She becomes a bag lady, and not part of the working class. 
From early childhood on she has been indoctrinated in an awareness of social hierarchies and the difference between her mother, a lady, and the maid down on her knees scrubbing the floor. "Alma is a maid, [my mother] explained when I asked. And I am a lady. You will be a lady one day, but now you are a little girl..." (Grenville, Lilian's Story, 5). When Lil herself is forced to clean the floor in prison, she is totally inadequate to the task and incurs punishment and ridicule at the hands of wardens and inmates for her inability to use a broom and for wiping up the suds with her blouse. In fact, the lower class prisoners are hostile to this eccentric middle class woman in their midst and exclude her from their community. Indeed, the prison is the only place where Lil almost dies of isolation and misery. Throughout her career Lil never does physical labour for a living. While she goes to University, she is supported by her father, and even later, thanks to her aunt, he gives her a small allowance and she also inherits some money from her kindly relative. When her funds dwindle, she joins her homeless friend Frank in the park, where she enjoys nature, the sky, the sea, and the closeness of Frank's body.

During her schooldays Lil realizes that girls cannot become heroes, only men - but she can shock and scandalize and thereby gain the fame she craves, and she does become a hero of sorts when she enters history by becoming an urban legend. As a homeless person she can follow her own desires, and the reader is made to feel that she has had a better life than if she had followed the conventional path, which would not have allowed her any of the experiences she relishes - and she has the gift to be happy with small things. Although she ends up as a pauper in an old people's home run by kindly nuns, her life is a triumph nonetheless. "You think you're Christmas ... you think you're someone special and you're not" (Grenville, Lilian's Story, 58-59), a spiteful school-friend tells her, yet capering around naked in the lunatic asylum she is still convinced that she is "Christmas and Easter and my birthday all at once" (Grenville, Lilian's Story, 195). "I have always been my own destiny, and loved my inventions of myself" (Grenville, Lilian's Story, 255), she tells the boy she admired at school, who has become a run-down Troskyite.

Her mad friend Jewel says: "I wish I was you, and regretted what you do" (Grenville, Lilian's Story, 257), because Lil only regrets the loss of the edition of Shakespeare's works her Father has destroyed - but by that time she knows enough of the Bard's verse by heart to keep her going. She also regrets not hitting a few people, not having married a young man called Stroud many years ago, and the many sights around the world she has not seen (Grenville, Lilian's Story, 256). Yet as a bag lady she can, nonetheless, shout to the crowd with conviction: "I am a contented woman, and wish for nothing, and they stared at me, and none could say the same for themselves" (Grenville, Lilian's Story, 259). Eccentricity grants her the freedom to move around the city (Barcan 49) because she defies the prohibition preventing the "free circulation" of middle class women "in public 
space" (Barcan 46). Thus marginalization and social decline, paradoxically, become a source of power (Barcan 51). At the end of her life she joyously shouts to a taxi chauffeur taking her on a birthday outing: "Drive on, George. I am ready for whatever comes next” (Grenville, Lilian's Story, 280).

As I have mentioned, Lillian makes a small living by reciting poetry in the streets. When she was a child, her eagerness to show off was considered unladylike and immodest, but her "appropriation of Shakespeare and the cultural capital it represents" (Ashcroft 67) serves to put into question not only Lil's supposed madness but also her social categorization. It deconstructs cliché images of derelict vagabonds. In Gail Jones' novel Sorry, too, Shakespeare becomes a marker of high culture, education and hence of social standing, though in this case the characters do not embrace downward mobility. In Sorry, Perdita's English mother obsessively quotes the Bard as a bulwark against descending into the poor underclass to which her living conditions in Australia consign her. In contrast, Bail's and Jefferis' drover's wives, as I have mentioned in the beginning, like Lil embrace downward social mobility as liberation. And like Lil, Jefferis' protagonist, too, prides herself on knowing seventy poems and hymns by heart, including texts by canonical English authors like Elizabeth Barrett-Browning and Christina Rossetti. In contrast, her middle-class husband, the dentist, hardly reads at all.

He couldn't read more than half a page of a book without getting bored and coming on worlds that were too big for him. I never knew him read anything much except for the racing pages in the paper and the labels on [medicine] bottles ... (Jefferis, 269-270)

Similarly, Lilian's father obsessively collects facts from newspapers or encyclopaedias, but he has no interest in literature. Both Lilian and Jefferis' drover's wife reject bourgeois norms and opt for a life outside social conventions, accepting downward social mobility to remain true to themselves; yet at the same time they embrace high culture and thereby stake a claim to an intellectual status far above that of the philistine middle class characters we meet in these texts.

\section{REFERENCES}

\section{Primary literature}

Bail, Murray. “The Drover's Wife." The Arnold Anthology of Post-Colonial Literatures in English. Ed. John Thieme. London/New York/Sydney/Auckland: Arnold, 1996. 255-259.

Grenville, Kate. Lilian's Story [1985]. Edinburgh/New York/Melbourne: Canongate, 1994. 
Grenville, Kate. The Secret River [2005]. Edinburgh/New York/Melbourne: Canongate, 2006.

Jefferis, Barbara. “The Drover's Wife." The Arnold Anthology of Post-Colonial Literatures in English. Ed. John Thieme. London/New York/Sydney/Auckland: Arnold, 1996. 265-272.

\section{Secondary literature}

Ashcroft, Bill. "Madness and Power. Lilian's Story and the Decolonized Body." Lighting Dark Places. Essays on Kate Grenville. Ed. Sue Kossew. Amsterdam/ New York: Rodopi, 2010, 55-72.

Barcan, Ruth. "Mobility is the Key': Bodies, Boundaries and Movement in Kate Grenville's 'Lilian's Story'. Ariel, Vol 29:2 (1998): 31-55.

Grenville, Kate: “Readers' Notes” (2005). http://kategrenville.com/Lilians_Story_Readers_Notes. Accessed 29 August 2016.

Livett, Kate. "Homeless and Foreign. The Heroines of Lilian's Story and Dreamhouse.” 119-134.

Margarete Rubik University of Vienna, Austria margarete.rubik@univie.ac.at

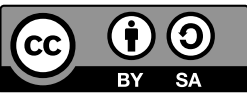

\section{Slavitev družbene mobilnosti navzdol v izbranih avstralskih tekstih}

Kljub tradicionalnemu avstralskemu moškemu literarnemu junaku iz nižjega razreda, številni novejši avstralski avtorji prikazujejo ženske junakinje, ki ustrezajo temu uporniškemu idealu nižjega razreda in tako umeščajo ženske $v$ nacionalni mit, avtorica predvsem obravnava Kate Grenville ter Barbaro Jefferis.

Ključne besede: avstralska proza, Kate Grenville, D.H. Lawrence, Murray Bail, Barbara Jefferis 